\title{
UTILIZATION OF PLANT EXTRACTS TO SUPPRESS Squash Mosaic Virus INFECTION ON RIDGED GOURD (Luffa acutangula [L.Roxb])
}

\author{
Maharani Mustika Putri \& Tri Asmira Damayanti \\ Department of Plant Protection, Faculty of Agriculture, IPB University, Indonesia \\ Jl. Kamper Kampus IPB Dramaga Bogor 16680 \\ E-mail: triadys@apps.ipb.ac.id
}

Manuscript received: 29 July 2020. Revision accepted: 26 August 2020.

\begin{abstract}
Utilization of plant extracts to suppress Squash Mosaic Virus Infection on ridged gourd (Luffa acutangula $[L]$. Roxb). Control effort strategies against plant pathogens are necessary to be explored and evaluated its effectiveness intensively. One environmentally friendly control method is biological control by using plant extracts. It is well known that cucurbits are cultivated widely in Indonesia. However, cucurbits are susceptible plants against various pathogens, including viruses. Recently, Squash mosaic virus (SqMV) found to infect cucurbits such as ridged gourd in West Java. The research aimed to explore and evaluate the effectiveness of plant extracts to suppress SqMV infection on the ridged gourd. Three selected plants, namely Bougainvillea spectabilis, Mirabilis jalapa, and Celosia cristata, were tested in greenhouse trial with aspirin as a comparison. The extract was sprayed on the leaves a day before mechanical virus infection. The disease assessments and agronomic parameters were observed. The plant extract treatment showed able to prolonged the incubation period, caused milder symptoms, reduced the virus titer, and showed better plant growth in compared with aspirin treatment or untreated control. B. spectabilis and M. jalapa crude leaf extract revealed able to suppress the SqMV infection with comparable effectiveness with relative inhibition level of disease severity and virus titer up to $48.2 \%$ and 80.6 to $81.4 \%$, respectively, indicating their potential as biocontrol for SqMV.
\end{abstract}

Key words: comovirus, Cucurbitaceae, induced systemic resistance, plant extracts

\section{INTRODUCTION}

The Cucurbitaceae family consisted of more than 800 species members. Many species in Cucurbitacecae are vegetables which contain the rich nutrient. One of the Cucurbitaceae members is Luffa acutangula (L.) Roxb. It is well known locally as oyong or gambas. Generally, Cucurbitaceae members are susceptible plants against various plant pathogens types such as bacteria, fungi and viruses, and also pests. However, plant viruses may play as production constraints of Cucurbitaceae (Rubatzky \& Yamaguchi, 1997).

Thirty-two viruses are belonging to genus cucumovirus, comovirus, potyvirus, begomovirus, and polerovirus that can infect Cucurbitaceae. Among those members, Squash mosaic virus (SqMV) is crucial in limiting cucurbit production worldwide. Infected plants showed typical mosaic symptoms on the leaves and fruits. SqMV can efficiently transmit by mechanically, insect vector, and seed transmission (CPC, 2007; Lestari \& Nurhayati, 2014). Until present, SqMV status is as quarantine pest A2, which is limitedly detected on cucurbits in West Java based on Permentan No. 31, 2018. However, based on recent data SqMV has been detected on cucumbers in Java Island (Listihani, 2018), indicating of its spread expansion on cucumber in Java.

Generally, plant virus management can be utilized chemical pesticides to control the insect vector, controlling seed importation via plant quarantine agency, using healthy seeds and resistant varieties. Among them, utilization of resistant variety is most useful to control plant pathogens, including against viruses infection. However, commercial resistant varieties are limitedly available in the markets. Thus, it is necessary to explore and evaluate some control strategies, such as induced systemic resistance (ISR). Induced resistance is a state of enhanced defensive capacity developed by a plant when appropriately stimulated. Plant defense mechanisms can be stimulated before pathogen infection by non-pathogenic microbes such as rhizosphere and endophytic bacteria and plant extracts, with the results that the disease reduced. Plant's active defense apparatuses can be actively expressed against various biotic stresses such as plant pathogens and phytophagous 
insects (Choudhary et al., 2007). Further, a chemical is a potential source to enhance plant resistance that plays essential roles in suppressing pathogens (Balasarawathi et al., 1998; Choudhary et al., 2007; Mahdy et al., 2010; Radwan et al., 2007). After sunflowers treated by salicylic acid (SA), antioxidant enzymes can be increased (Sedghi et al., 2013). The control method is categorized as biological control, which environmentally friendly. Its role in plant protection needs to be explored and studied intensively in Indonesia.

Many plant species is contain some antiviral substances, namely basic protein. The protein's mode action to suppress virus infection in plants is through activation of antiviral by ribosome-inactivating proteins (RIPs) and ISR (Vivanco et al., 1999). Plant extracts able to suppress the infection of viruses such as Cucumber mosaic virus (CMV), Tobacco mosaic virus (TMV), Tomato mosaic virus (ToMV), Tomato spotted wilt virus (TSWV), Potato virus $Y$ (PVY), Potato virus X (PVX), Potato leafroll virus (PLRV), Potato tuber spindle viroid (PSTVd), Cucumber green mottle mosaic virus (CGMMV), Turnip mosaic virus (TuMV), Bitter gourd yellow mosaic virus (BGYMV) and Bean common mosaic virus (BCMV) (Balasarawathi et al., 1998; Balasubrahmanyam et al., 2000; Baranwal \& Verma, 1997; Damayanti \& Panjaitan, 2014; Deepthi et al., 2007; Gholizadeh et al., 2004; Hersanti, 2004; Kubo et al., 1990; Kumalasari et al., 2015; Kurnianingsih \& Damayanti, 2012; Madhusudhan et al., 2011; Rajinimala et al., 2009; Sharma et al., 2007). The effectiveness of plant extracts to suppress the virus infection is depends on the virus species. Previously, the leaf extract of Mirabilis jalapa, Celosia cristata, and Bougainvillea spectabilis reported inhibiting BCMV infection up to $100 \%$ (Damayanti \& Panjaitan, 2014).

Plant systemic resistance also can be induced by a chemical such as salicylic acid (SA) with pathogen inhibition mechanism similar to ISR. Salicylic acid is one of the chemical defense in plant systems to restrict infection of either obligate such plant viruses or nonobligate pathogens (Mahdy et al., 2010; Radwan et al., 2007; Sujatmiko et al., 2012; Vivanco et al., 1999). Since those extracts' ability to suppress SqMV infection is still unknown yet, and SqMV is considerate as quarantine pest, it is necessary to explore and evaluate the effectiveness of control methods to mitigate the virus infection.

\section{MATERIALS AND METHODS}

Research Site. The experiment was conducted from February to July 2016 in the greenhouse at Cikabayan, Dramaga, Bogor and serological detection of SqMV from tested plants were carried out at Laboratory of Plant Virology, Department of Plant Protection, Faculty of Agriculture, IPB University.

Plant Preparation. Seeds were planted in polybag containing a mixture of sterilized soil and dung manure in ratio 1:1 (w/w). Two seeds were planted each polybag. Seven days after seeding, the plant with the best growth condition is selected for the treatment.

SqMV Propagation by Mechanical Transmission. SqMV ridged gourd isolate belongs to Laboratory of Plant Virology, Department of Plant Protection, Faculty of Agriculture, IPB University. SqMV propagated on ridged gourd var. Azura by mechanical transmission. SqMV inoculum from infected plants $(0.1 \mathrm{~g})$ soaked with liquid nitrogen, then was ground in a mortar until became powder. Phosphate buffer $\mathrm{pH} 7.0$ containing $1 \% \beta$-mercaptoethanol $(1: 10 \mathrm{w} / \mathrm{v})$ was added to leaf powder to homogenized the leaf sap. The cotyledon of healthy plants 7 days after sowing (DAS) was rubbed with abrasive carborundum 600 mesh, then leaf sap containing virus was inoculated mechanically onto the first leaves with a finger. After mechanical inoculation, cotyledons were rinsed by tap water to remove the carborundum. Plants were maintained in the greenhouse and watering every day.

Preparation of Aqueous Leaf extracts. The aqueous extract was extracted according to a previously described method (Deepthi et al., 2007) with minor modification in dilution ratio from 1:1 (w/v) to $1: 5(\mathrm{w} / \mathrm{v})$. Each plant leaves of $B$. spectabilis (BS), M. jalapa (MJ) and C. cristata (CC) was ground in liquid nitrogen by using a pestle, then buffer phosphate was added to the leaf powder with ratio 1:5 (w/v). The leaf sap was sieved using double-layered cheesecloth to separate from debris. The aqueous extract was centrifuged at 10,000 rpm for $10 \mathrm{~min}$. The supernatant was collected and used for further study. Aspirin containing SA (encoded AS) $0.5 \%$ was diluted in buffer phosphate as a comparison. 
Treatment. Each crude extract (encoded by BS, MJ, $\mathrm{CC}$ ) and aspirin (AS) was sprayed onto the ridged gourd leaves (6 DAS). Untreated plants healthy plants without virus $(\mathrm{H})$ and untreated plants infected by the virus $(\mathrm{C})$ were used as control treatments. Control plants were sprayed by sterile buffer phosphate. A day after treatments (7 DAS), all test plants were challenge inoculated mechanically by SqMV, except for healthy control plants. All plants were maintained in the greenhouse up to 8 weeks post virus inoculation (WPI) and cultivated according to ridged gourd cultivation methods (Edi \& Bobihoe, 2010).

Observation Parameter. Disease assessment (incubation period, type of symptom, disease incidence and severity, virus titer) and agronomic parameters (height, number of leaf and flower, phenotype roots) were observed from 1-8 WPI. The incubation period was observed from 1 WPI until first symptom present. Type of symptom was observed from 1-8 WPI. Disease severity was measured every week up to 8 WPI. Determination of disease severity by using severity scale described previously (Ayo-John et al., 2014). Score 1No symptom, 2-mild mosaic (10\% of leaves), 3-moderate symptom (10-30\% of leaves), 4 -severe symptom ( 30 $50 \%$ ), 5-leaf distortion and death (over 75\%).

Relative Inhibition Level (RIL) of severity was measured with formula:

RIL severity (i) $=\frac{\text { Severity }(C)-\text { Severity treatment }(i)}{\text { Severity }(C)} \times 100 \%$

Serological Detection by Double Antibody Sandwich ELISA (DAS-ELISA). Virus titer was determined serologically by DAS-ELISA using SqMV specific antiserum according to the protocol provided by Agdia. Leaf samples were collected at 4 WPI from each treatment. Each treatment consisted of 5 composite samples. DAS-ELISA step was started from coating plate ELISA in carbonate coating buffer $\left(\mathrm{Na}_{2} \mathrm{CO}_{3}\right.$ $1.59 \mathrm{~g}, \mathrm{NaHCO}_{3} 2.93 \mathrm{~g}, \mathrm{NaN}_{3} 0.2 \mathrm{~g}$ in $1000 \mathrm{~mL}$ aquabidest) containing the first antiserum for overnight at $4{ }^{\circ} \mathrm{C}$. The next day, coated ELISA plate was washed by using PBST buffer pH7.4 (NaCl $8 \mathrm{~g}, \mathrm{Na} 2 \mathrm{HPO} 4$ $1.15 \mathrm{~g}, \mathrm{KH}_{2} \mathrm{PO}_{4} 0.2 \mathrm{~g}, \mathrm{KCl} 0.2 \mathrm{~g}$, aquabides $1000 \mathrm{~mL}$, Tween-20 $0.5 \mathrm{~mL}$ ), coating antigen step using General extract buffer $\mathrm{pH} 7.4\left(\mathrm{Na}_{2} \mathrm{SO}_{3} 1.3 \mathrm{~g}, \mathrm{NaN}_{3} 0.2 \mathrm{~g}, \mathrm{PVP}\right.$ [polyvinyl pyrrolidone] $20 \mathrm{~g}$, Powdered egg albumin grade II $2 \mathrm{~g}$, Tween-20 $20 \mathrm{~g}$ in $1000 \mathrm{~mL}$ PBST) for $3 \mathrm{~h}$ at temperature $37^{\circ} \mathrm{C}$. The $2^{\text {nd }}$ antiserum was diluted in ECI buffer (BSA [bovine serum albumin] 2 g, PVP
MW 24-40 $20 \mathrm{~g}, \mathrm{NaN}_{3} 0.2 \mathrm{~g}$ in $1000 \mathrm{~mL}$ PBST, pH 7.4), put into each well, and incubated for $3 \mathrm{~h}$ at temperature $37{ }^{\circ} \mathrm{C}$. After washing step, ELISA plate was stained by addition of PNP (p-nitrophenyl phosphate) diluted in substrate buffer $\left(\mathrm{NaN}_{3} 0.2 \mathrm{~g}, \mathrm{MgCl}_{2}{ }_{6} \mathrm{H}_{2} \mathrm{O}\right.$ $0.1 \mathrm{~g}$, Diethanolamine $97.0 \mathrm{~mL}$ in $1000 \mathrm{~mL}$ aquabidest, $\mathrm{pH} 9.8$ ) into test wells. Positive reaction if PNP substrate in the test well changed to yellow after 30-60 min incubated at room temperature. Virus titer was measured on ELISA reader at wavelength $405 \mathrm{~nm}$. Positive reaction occurred if ELISA absorbance value (EAV) of test sample twice of healthy EAV samples. RIL virus was measured by using the formula;

$$
\text { RIL virus }(\mathrm{i})=\frac{\operatorname{EAV}(\mathrm{C})-\mathrm{EAV} \text { treatment }(\mathrm{i})}{\operatorname{EAV}(\mathrm{C})} \times 100 \%
$$

Data Analysis. The experiment was arranged in complete randomized design; consisting of 6 treatments with 15 plants each treatment as replicate. The data is analyzed by ANOVA using software SPSS v21.0 (Statistical Package for Social Sciences, USA) and followed by Duncan's Multiple Range Test (DMRT) at significant level $5 \%$.

\section{RESULTS AND DISCUSSION}

The effect of plant extract treatments on disease parameters was varied; it depends on the extract. The incubation period of treated plants showed significantly longer compared with untreated control and aspirin treatment. The incubation period of treated plants ranging from 8.8 to 11.2 -days post virus inoculation (DPI), while untreated control was 3.3 DPI and aspirin (AS) treatment was 4.5 DPI (Table 1). It indicates that plant extract treatment may inhibit virus replication at an early stage of infection by producing either antiviral substances or virus inhibitor. Virus inhibitor, in particular, leaf sap, contains a substance that can prevent virus infection (Kumalasari et al., 2015). Some pathogen inhibitors, such as flavonoid, chitinase, phytoalexin, peroxidase, polyphenol, oxidase, lipoxidase, and others (Choudhary et al., 2007). Almost all virus inhibiting substances from higher plants are recognized as basic proteins (Deepthi et al., 2007; Verma et al., 1998). However, the extracts treatment showed lower disease incidence than other treatments only on plant treated with M. jalapa and C. cristata (Table 1).

Generally, plant extracts treatment effect to disease severity. At the early infection stage, chlorotic spots and mosaic are general symptoms on all test plants. However, untreated control and AS treated plants showed more severe symptoms than extract-treated plants such 
as mosaic, cupping, vein clearing, vein banding, blotch, and leaf malformation (Figure 1). The development of disease severity increased every week. All treated plants showed significantly lower severity; milder symptoms compared with untreated control and AS treated plants. The peak of disease severity showed at 4 WPI and slow down up to 8 WPI (Figure 2). After the virus infects its host and reaches the peak of infection, the severity and the virus will decrease because of increasing plant defense response during increasing plant age. RIL of severity at 4 WPI of treated plants ranged from 8.25 $48.25 \%$, and AS treatment showed the lowest RIL in comparison with extract treatments.

The disease severity score correlates with the virus titer by a serological test. All plant extracts treatments can reduce the virus titer significantly compared to untreated control and AS treatments. Based on ELISA absorbance value (EAV), the SqMV are negatively detected on BS, and MJ treated plants; the highest relative inhibition level of virus titer after treatment revealed by BS and MJ treatments, respectively. $\mathrm{CC}$ treatment can reduce the virus titer, however its ability lower than BS and MJ treatments, while AS treatment unable to inhibit the virus titer (Table 2). These data suggested that BS and MJ treatment could suppress severity and virus titer, indicating that both plant extracts contain antiviral substances to suppress SqMV significantly. B. spectabilis extract contains Bougainvillea antiviral proteins (BAPs), while $M$. jalapa extract contains Mirabilis antiviral proteins (MAPs) and C. cristata contains Celosia cristata antiviral protein (CCP) (Balasarawathi et al.,

Table 1. Effect of treatment on incubation period and disease incidence

\begin{tabular}{lcc}
\hline Treatment & Incubation periods (day) $^{\mathrm{a}}$ & ${\text { Disease incidence }(\%)^{\mathrm{b}}}^{\mathrm{b}}$ \\
Healthy plants & - & - \\
Untreated control & $3.3 \pm 0.2 \mathrm{a}$ & 100 \\
Aspirin & $4.5 \pm 0.7 \mathrm{a}$ & 100 \\
B. spectabilis & $11.2 \pm 3.5 \mathrm{~b}$ & 100 \\
M. jalapa & $10.7 \pm 1.2 \mathrm{~b}$ & 93 \\
C. cristata & $8.8 \pm 1.2 \mathrm{~b}$ & 86 \\
\hline
\end{tabular}

${ }^{a}$ Number in same column followed by same letter is not significantly difference based on DMRT at 5\% significant level.

${ }^{\mathrm{b}}$ Disease incidence $=$ number of infected plants/total test plants $\times 100 \%$.

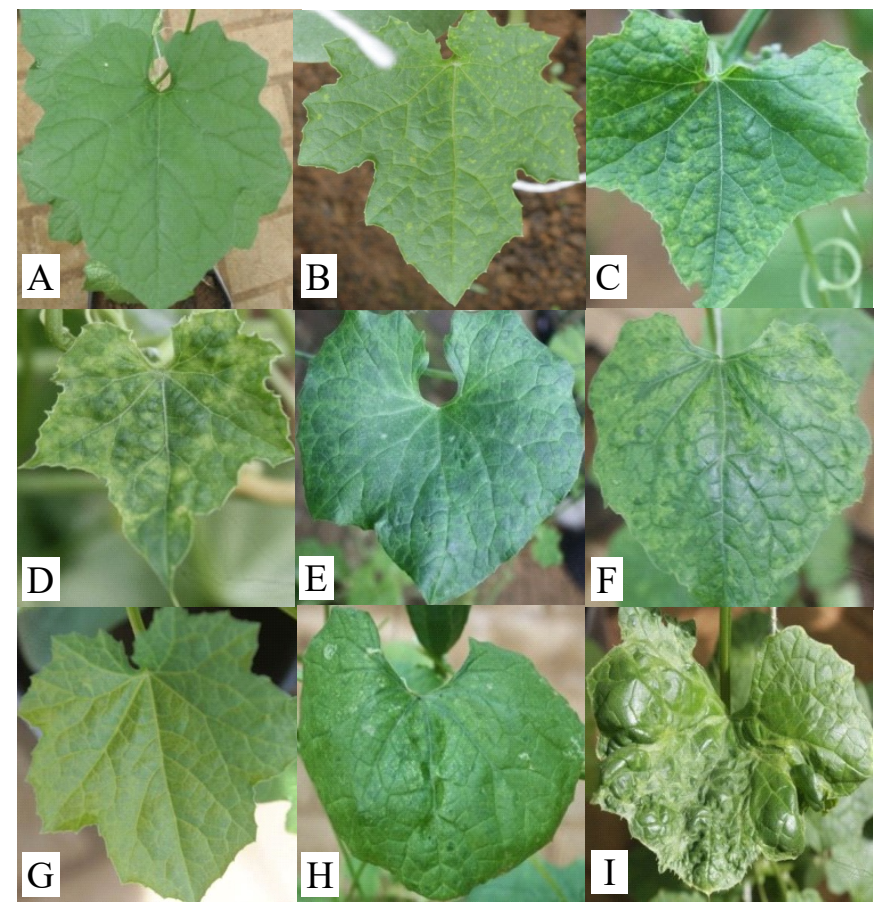

Figure 1. Symptom variation on SqMV infected plants. (A) Healthy; (B) Initial symptom; (C) Chlorosis spots; (D) Yellow mosaic; (E) Green mosaic; (F) Vein banding; (G) Vein clearing; (H) Cupping; (I) Blotch. 
1998; Balasubrahmanyam et al., 2000; Gholizadeh et al., 2004). BAPs and MAPs are called ribosomeinactivating proteins (RIPs) (Verma et al., 1998). While the CCP is known as potent antioxidants that can increase antioxidant enzyme activity such as peroxidase, catalase, and polyphenol oxidase on TMV inoculated plants (Baranwal \& Verma, 1997; Gholizadeh et al., 2004). In this case, BAPs may interfere with protein synthesis of SqMV, and able to reduce virus protein to an undetectable level by ELISA (Table 2) as previously reported by Balasaraswathi et al. (1998).

The intensity of symptom expression varied depending on host-virus and temperature during disease development (Agrios, 2005). Symptom expression is not always positively correlated with virus concentration in plants. Many factor affect the correlation between disease severity and virus titer such as host plant, pathogen, the interaction between plant-pathogens and environment factors, namely temperature, humidity, light, soil nutrient, and $\mathrm{pH}$ plays a role in the development of plant disease. Those abiotic factors affect plant growth or plant susceptibility, multiplication and pathogen activity, plant-pathogen interaction, and disease severity (Hull, 2013). The environmental condition for ridged gourd growth temperature is at $18-24{ }^{\circ} \mathrm{C}$ and relative humidity at $50-60 \%$ (Edi \& Bobihoe, 2010). The temperature during experiments ranging from $29-40{ }^{\circ} \mathrm{C}$ with relative humidity ranged from $42-69 \%$. These abiotic stresses affect symptom expression more obvious, although treated plants contain lower virus titer.

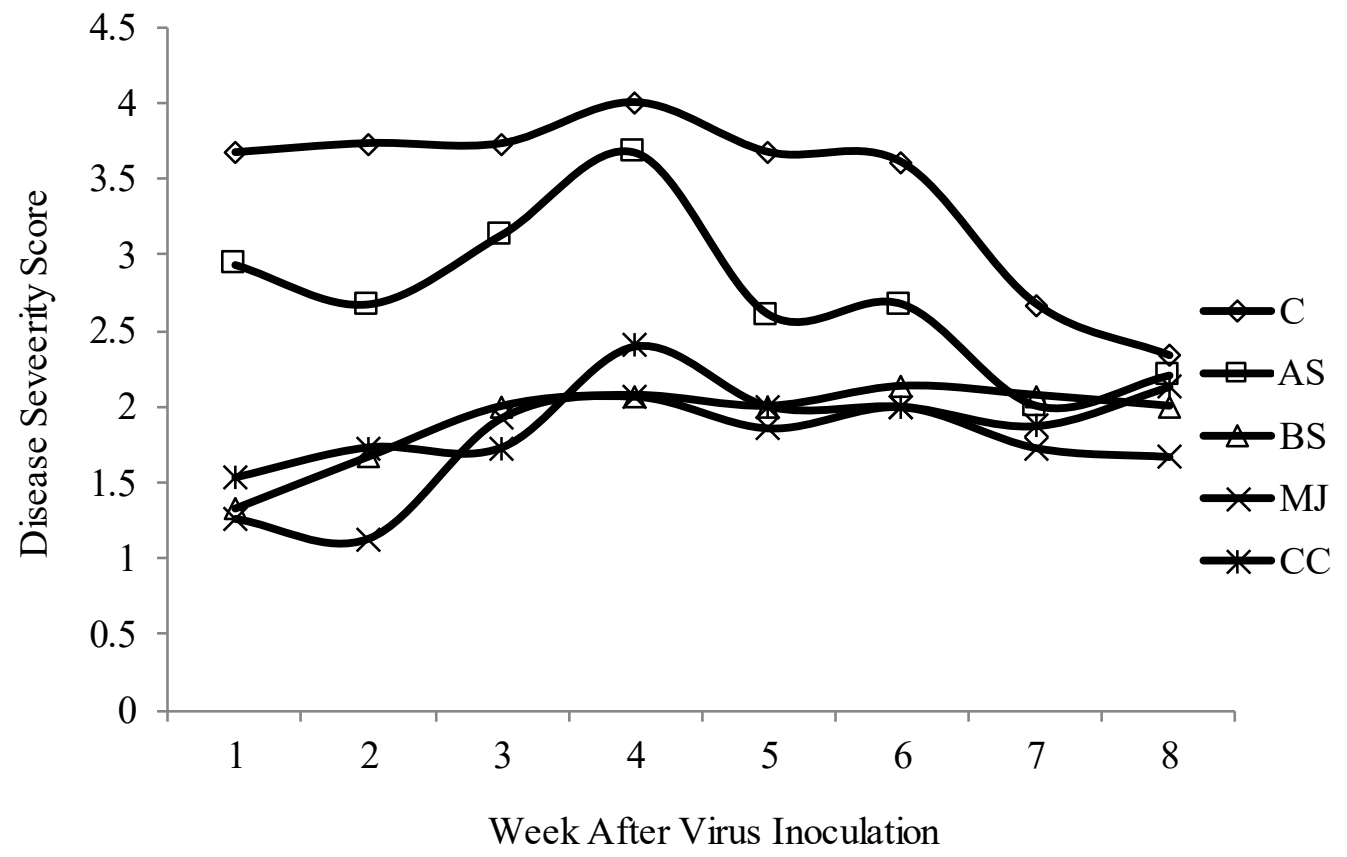

Figure 2. Development of disease severity at 1-8 weeks post virus inoculation. Treatments: (C) Untreated control; (AS) Aspirin; (BS) B. spectabilis; (MJ) M. jalapa; (CC) C. cristata.

Table 2. Disease severity, virus titer and relative inhibition level (RIL)

\begin{tabular}{|c|c|c|c|c|c|}
\hline Treatment & $\begin{array}{l}\text { Disease severity }^{\mathrm{a}} \\
\quad(\text { mean } \pm \mathrm{SD})\end{array}$ & $\begin{array}{c}\text { RIL severity } \\
(\%)\end{array}$ & $\frac{\mathrm{EAV}^{\mathrm{b}}}{(\text { mean } \pm \mathrm{SD})}$ & Note $^{\mathrm{c}}$ & $\begin{array}{c}\text { RIL virus } \\
(\%)\end{array}$ \\
\hline Healthy control $(-)^{d}$ & - & - & 0.172 & - & - \\
\hline ELISA control $(+)^{\mathrm{e}}$ & - & - & 0.465 & + & - \\
\hline Untreated control & $4.00 \pm 0.84 b^{f}$ & 0.00 & $0.911 \pm 0.15 b c$ & + & 0.00 \\
\hline Aspirin & $3.67 \pm 1.05 \mathrm{~b}$ & 8.25 & $1.159 \pm 0.15 \mathrm{c}$ & + & -27.22 \\
\hline B. spectabilis & $2.07 \pm 0.59 \mathrm{a}$ & 48.25 & $0.169 \pm 0.01 \mathrm{a}$ & - & 81.45 \\
\hline M. jalapa & $2.07 \pm 0.59 \mathrm{a}$ & 48.25 & $0.176 \pm 0.21 \mathrm{a}$ & - & 80.68 \\
\hline C. cristata & $2.40 \pm 0.63 \mathrm{a}$ & 40.00 & $0.636 \pm 0.33 b$ & + & 30.19 \\
\hline
\end{tabular}

${ }^{a}$ at 4 week post virus inoculation; ${ }^{b}$ ELISA absorbance value; 'Positive reaction if EAV $\geq 0.344$ ( $2 x$ of EAV healthy control); ${ }^{\text {d,e }}$ control ELISA test; ${ }^{\mathrm{f}}$ Number in the same column followed by same letter is not significantly difference based on DMRT at 5\% significant level. 
The virus titer of AS treated plants was not significantly different from untreated control plants, indicating that $\mathrm{AS}$ unable to suppress the virus infection by enhancing plant resistance. Since SA in aspirin is created by a chemical reaction between salicylic acid and acetic acid (Acetylsalicylic acid), it might less ability to increase plant resistance despite AS contain salicylic acid. Previously, SA dissolved in distilled water reported able to suppress zucchini yellow mosaic virus (ZYMV), cucumber mosaic virus (CMV), and tobacco mosaic virus (TMV) infection (Naylor et al., 1998; Radwan et al., 2007). SA dissolved in 70\% ethanol showed a highly effective antiviral against the influenza virus (Glatthaar-Saalmüller et al., 2017). It is indicating that SA performance depends on the solvent type. In this study, AS was dissolved in phosphate buffer as comparison, suggesting that it caused inhibit SA performance as plant defense inducer.

The results revealed that the application of plant extracts could prolong the incubation period, reduce disease severity, and virus titer. It is indicating those of plant extracts contain antiviral substances which able to suppress SqMV infection. Prolong incubation period might occur by increasing salicylic acid after treatment, which inhibits systemic movement of the virus via phloem and will prevent initial disease symptoms indirectly
(Naylor et al., 1998). Further, the application of plant extracts before challenge inoculation of the virus indicates that those of plant extracts may able to enhance plant resistance. Inhibition of virus infection by $B$. spectabilis and $M$. jalapa extract was through BAPs and MAPs activities. It also increased plant resistance, which activates plant defense mechanisms in susceptible hosts called systemic resistance inducers (SRIs) (Verma et al., 1998). Improving plant systemic resistance will increase the peroxidase and salicylic acid in plants (Vivanco et al., 1999). B. spectabilis, $M$. jalapa, and $C$. cristata application showed conclusively inhibit lesion local necrotic formation of bean common mosaic virus (BCMV) on Chenopodium amaranticolor and yard long bean (Damayanti \& Panjaitan, 2014). The effectiveness of B. spectabilis, M. jalapa, and C. cristata to control SqMV extend those extracts' utilization to control plant viruses. Further study is necessary to conduct to determine the mechanism of those extracts as antiviral and systemic resistance inducer against SqMV.

SqMV infection affects the agronomic parameter; virus infection reduces plant height, leaf, and flower number (Table 3), and root development (Figure 3) on untreated control plants. All treated plants showed better vigor in comparison with untreated control. BS treatment

Table 3. Effect of treatment on growth parameter

\begin{tabular}{lccc}
\hline \multirow{2}{*}{ Treatment } & \multicolumn{3}{c}{ Agronomic parameter } \\
\cline { 2 - 4 } & Height $(\mathrm{cm})$ & Leaf number & Flower number \\
\hline Healthy & $373.8 \pm 34.2 \mathrm{c}$ & $31.9 \pm 4.6 \mathrm{~b}$ & $7.9 \pm 2.7 \mathrm{c}$ \\
Untreated control & $298.5 \pm 43.6 \mathrm{a}$ & $29.8 \pm 3.3 \mathrm{ab}$ & $3.5 \pm 2.3 \mathrm{a}$ \\
Aspirin & $323.4 \pm 43.0 \mathrm{ab}$ & $29.0 \pm 3.6 \mathrm{ab}$ & $4.9 \pm 4.5 \mathrm{ab}$ \\
B. spectabilis & $343.3 \pm 35.5 \mathrm{bc}$ & $30.7 \pm 3.2 \mathrm{~b}$ & $6.2 \pm 3.8 \mathrm{bc}$ \\
M. jalapa & $320.1 \pm 54.1 \mathrm{ab}$ & $27.5 \pm 3.5 \mathrm{a}$ & $4.2 \pm 3.1 \mathrm{ab}$ \\
C. cristata & $305.6 \pm 53.6 \mathrm{a}$ & $31.7 \pm 4.5 \mathrm{~b}$ & $4.6 \pm 2.9 \mathrm{ab}$ \\
\hline
\end{tabular}

${ }^{a}$ Number in same column followed by same letter is not significantly difference based on DMRT at $5 \%$ significant level.

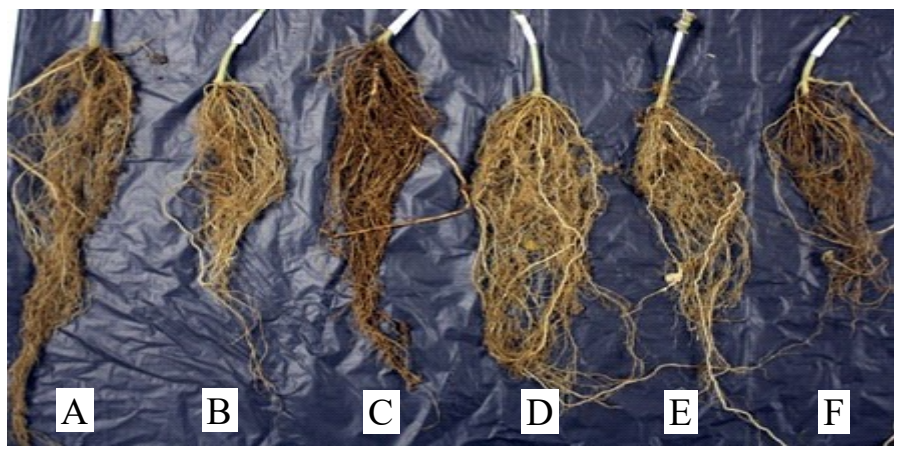

Figure 3. Effect treatment on root development. (A) Healthy; (B) Untreated control; (C) C. cristata; (D) B. spectabilis; (E) M. jalapa; (F) Aspirin. 
showed better growth vigor comparable with healthy plants. Plants treated with BS and AS showed stronger and straight stem than MJ and CC treated plants (data not shown). It is indicated that BS and AS have a positive effect on plant growth.

Similarly, bitter gourd plants treated with B. spectabilis (BS) challenge inoculated with bitter gourd yellow mosaic virus (BGYMV) reduced the disease incidence and increased plant growth (Rajinimala et al., 2009). Salicylic acid is known as an inducer of plant defense responses against pathogens. Further, seed germination, photosynthesis, protection to oxidative stress, respiration, vegetative growth and rate are also regulated by SA; it plays a crucial role in regulating physiological and biochemical processes during entire lifespan of the plant (Vicente \& Placensia, 2011). The leaf number of all treated plants was not significantly different, but leaves treated with BS leaf extract were larger and greener than other treatments. Previously, bitter gourd plants treated with B. spectabilis challenge inoculated with BGYMV reduced the disease incidence and increased plant growth. These results showed that leaf extract treatments could enhance plant resistance and have an antiviral activity to reduce virus replication and the disease severity (Table 2). Thus, virus-infected plants still able to grow better as well as healthy plants.

\section{CONCLUSION}

Application of leaf extract of $B$. spectabilis, $M$. jalapa and $C$. cristata revealed the ability to suppress disease severity caused by SqMV ranging from 40.0 to $48.2 \%$. Among them, the leaf extract of $B$. spectabilis, and M. jalapa able to decrease virus titer $81.45 \%$ and $80.68 \%$, respectively. Nevertheless, $B$. spectabilis showed the best ability as antiviral, systemic resistance inducer and plant growth enhancer. These plant species have potential as a bio-control agent for plant viruses. Further, research of appropriate formulation for field application is necessary to conduct in the future.

\section{ACKNOWLEDGMENTS}

This research partially supported by international plant virus disease network for providing antiserum. We would like to thank the Head of Plant Protection Department, Faculty of Agriculture, IPB University for the research facilities.

\section{REFERENCES}

Agrios GN. 2005. Plant Pathology $5^{\text {th }}$ edition. Academic Press. Elsevier.

Ayo-John EI, Olorunmaiye PM, Odedara OO, Dada OB, Abiola KO, \& Oladukun JO. 2014. Assessment of field-grown cucurbit crops and weeds within farms in South-West Nigeria for viral disease. Not. Sci. Biol. 6(3): 321-325.

Balasarawathi R, Sadasivam S, Ward M, \& Walker JM. 1998. An antiviral protein from Bougainvillea spectabilis roots, purification and characterization. Phytochemistry 47(8): 15611565 .

Balasubrahmanyam A, Baranwal VK, Lodha ML, Varma A, \& Kapoor HC. 2000. Purification and properties of growth stage-dependent antiviral proteins from the leaves of Celosia cristata. Plant Sci. 154(1): 13-21.

Baranwal VK \& Verma HN. 1997. Characteristics of a virus inhibitor from the leaf extract of Celosia cristata. Plant Pathol. 46(4): 523-529.

CPC (Crop Protection Compendium). 2007. Crop Protection Global Module. CABI, Wallingford.

Choudhary DK, Prakash A, \& Johri BN. 2007. Induced systemic resistance (ISR) in plants: mechanism of action. Indian J. Microbiol. 47(4): 289-297.

Damayanti TA \& Panjaitan MT. 2014. Aktivitas antivirus beberapa ekstrak tanaman terhadap Bean common mosaic virus strain black eye cowpea (BCMV-B1C) pada kacang panjang. J. HPT Tropika. 14(1): 32-40.

Deepthi N, Madhusudhan KN, Shankar ACU, Kumar HB, Prakash HS, \& Shetty ES. 2007. Effect of plant extracts and acetone precipitated proteins from six medical plants against tobamovirus infection. Int. J. Virol. 3(2): 80-87.

Edi S \& Bobihoe J. 2010. Budidaya Tanaman Sayuran. Balai Pengkajian Teknologi Pertanian Jambi, Jambi.

Gholizadeh A, Kumar M, Balasubrahmanyam S, Sharma S, Narwal S, Lodha ML, \& Kapoor HC. 2004. Antioxidant activity of antiviral proteins from Celosia cristata. J. Plant Biochem. Biotechnol. 13(1): 13-18. 
Hersanti. 2004. Pengaruh ekstrak beberapa tumbuhan dalam menginduksi ketahanan sistemik tanaman cabai merah (Capsicum annuum L.) terhadap Cucumber Mosaic Virus (CMV). Dissertation. Universitas Padjadjaran, Bandung.

Hull R. 2013. Matthews' Plant Virology. $4^{\text {th }}$ edition. Academic Press, Elsevier.

Kubo S, Ikeda T, Imaizumi S, Takanami Y, \& Mikami Y. 1990. A potent plant virus inhibitor found in Mirabilis jalapa L. Ann. Phytopath. Soc. Japan. 56(4): 481-487.

Kumalasari RN, Martosudiro M, \& Hadiastono T. 2015. Pengaruh berbagai jenis ekstrak nabati terhadap infeksi Cucumber mosaik virus (CMV) pada tanaman mentimun (Cucumis sativus L.). J. HPT. 3(1): 30-35.

Kurnianingsih L \& Damayanti TA. 2012. Lima ekstrak tumbuhan untuk menekan infeksi Bean common mosaic virus pada tanaman kacang panjang. $J$. Fitopatol. Indones. 8(6): 155-160.

Lestari SM \& Nurhayati E. 2014. Efisiensi tular benih Squash mosaic virus pada Cucurbitaceae. J. Fitopatol. Indones. 10(3): 81-86.

Listihani. 2018. Distribusi dan identifikasi virus utama pada mentimun di Jawa. Thesis. Institut Pertanian Bogor, Bogor.

Madhusudhan KN, Vinayarani G, Deepak SA, Niranjana SR, Prakash HS, Singh GP, Sinha AK, \& Prasad BC. 2011. Antiviral activity of plant extracts and other inducers against Tobamoviruses infection in bell pepper and tomato plants. Int. J. Plant Pathol. 2(1): 35-42.

Mahdy AMM, Hafez MA, EL-Dougdoug KhA, Fawzy RN, \& Shahwan ESM. 2010. Effect of two biotic inducers on salicylic acid induction in tomato infected with Cucumber mosaic cucumovirus. Egyptian J. Virol. SP issue: 355-372.

Naylor M, Murphy AM, Berry JO, \& Carr JP. 1998. Salicylic acid can induce resistance to plant virus movement. MPMI. 11(9): 860-868.
Radwan DEM, Fayez KA, Mahmoud SY, Hamad A, \& Lu G. 2007. Physiological and metabolic changes of Cucurbita pepo leaves in response to Zucchini yellow mosaic virus (ZYMV) infection and salicylic acid treatments. Plant Physiol. Biochem. 45(6-7): 480-489.

Rajinimala N, Rabindran R, \& Ramaiah M. 2009. Management of Bittergourd yellow mosaic virus (BGYMV) by using virus inhibiting chemical, biocontrol agents, antiviral principles (AVP) and insecticide. Arch. Phytopathol. Plant Protect. 42(8): 738-750.

Rubatzky VE \& Yamaguchi M. 1997. World Vegetables: Principles, Production, and Nutritive Value. Springer, California.

Glatthaar-Saalmüller G, Mair KH, \& Saalmüller A. 2017. Antiviral activity of aspirin against RNA viruses of the respiratory tract-an in vitro study. Influenza Other Respir. Viruses. 11(1): 85-92.

Sedghi M, Basiri HK, \& Sharifi RS. 2013. Effect of salicylic acid on the antioxidant enzymes activity in Sunflower. AWUT-serBio. 16(2): 67-72.

Sharma U, Thakur PD, Handa A, Bhaik A, \& Gupta D. 2007. Effect of Centella asiatica and Vitex negundo against TuMV infecting radish. J. Plant. Dis. Sci. 2(1): 22-25.

Sujatmiko B, Sulistyaningsih E, \& Murti RH. 2012. Studi ketahanan melon (Cucumis melo L) terhadap layu Fusarium secara in vitro dan kaitannya dengan asam salisilat. Ilmu Pertan. 15(2): 1-18.

Verma HN, Baranwal VK, \& Srivastava S. 1998. Antiviral substances of plant origin. In: Hadidi A, Khetarpal RK, \& Koganezawa H (Eds.). Plant Viruses Diseases Control. pp. 154-162. APS Press, St. Paul (US).

Vicente MRS \& Plasencia J. 2011. Salicylic acid beyond defence: its role in plant growth and development. J. Exp. Bot. 62(10): 3321-3338.

Vivanco JM, Querci M, \& Salazar LF. 1999. Antiviral and antiviroid activity of MAP-containing extracts from Mirabilis jalapa roots. Plant Dis. 83(12): 1116-1121. 